Katarzyna Arciszewsika-Tomczak Uniwersytet Gdański

\title{
RADZIECKI RUCH PIONIERSKI W POWIEŚCI ПИЩЕБЛОК ALEKSIEJA IWANOWA — DOŚWIADCZENIE POKOLENIOWE W NOWEJ PERSPEKTYWIE
}

\author{
SOVIET BOY SCOUTS IN ALEKSEY IVANOV'S NOVEL ПИЩЕБЛОК - \\ THE EXPERIENCE OF A GENERATION FROM A NEW PERSPECTIVE
}

The main subject of this article is an analysis of the novel Пищеблок. The author of the article gives special attention to the theme of vampirism, used by Ivanov as a metaphor for the authoritarian Soviet system and its influence on citizens of the USRR, especially on scouts. Scouting can be described as a generational experience of the inhabitants of the Soviet Union. To present scouting in the USRR, the writer recreates the nostalgia of childhood, describing in the process the political and propagandistic aspects of scouting. The article also presents literary production of Ivanov.

Keywords: Aleksey Ivanov, scouting, scout camp, childhood, vampires

СОВЕТСКОЕ ПИОНЕРСКОЕ ДВИЖЕНИЕ В РОМАНЕ ПИЩЕБЛОК

АЛЕКСЕЯ ИВАНОВА - ОПЫТ ПОКОЛЕНИЙ

В НОВОЙ ПЕРСПЕКТИВЕ

В статье представлен анализ указанного в заглавии романа Пищеблок Алексея Иванова. В тексте обращается внимание на использование Ивановым мотива вампиризма, который автор рассматривает как метафору власти и ее влияние на жителей Советского Союза, главным образом на пионерскую 
молодежь. Пионерское движение как опыт поколений представляет Иванов через призму ностальгии детских воспоминаний, но и агитационной деятельности пионерской организации. В статье подчеркнуты также черты творчества Иванова и коротко представлена его творческая деятельность. Ключевые слова: Алексей Иванов, пионерское движение, пионерский лагерь, детство, вампиризм

Pod koniec 2018 roku ukazała się na rosyjskim rynku wydawniczym powieść Aleksieja Iwanowa Пищеблок¹. Twórczość pisarza nie jest jeszcze powszechnie znana w Polsce, w Rosji natomiast autor ten cieszy się popularnością wśród czytelników oraz uznaniem krytyki. Jelena Szubina mówi o Iwanowie: „Алексей Иванов - удивительно многогранный писатель, который пишет о разном и по-разному, но всякий раз - блестяще"”. Opinię o różnorodności tematycznej, stylistycznej i gatunkowej twórczości autora potwierdza on sam, choć jednocześnie przyznaje się do pewnych ograniczeń w zakresie literackiego eksperymentu:

Я думаю, что меня вполне справедливо назвать экспериментатором. В каждом новом произведении я меняю жанр и подходы. Я не экспериментатор в чистом виде, который пробует что-то новое для культуры, но я всегда пробую что-то новое для себя³

Wieloaspektowość swojego dorobku Iwanow tłumaczy specyfiką podejścia do rzeczywistości - współczesnej i historycznej. Pisarz obserwuje ją i reaguje na palące problemy danej epoki, ilustruje je oraz stara się, by poprzez jego prozę przeniknęły do świadomości odbiorców. W procesie twórczego opracowywania wyselekcjonowanego tematu autor dokonuje wyboru gatunku lite-

\footnotetext{
${ }^{1}$ А. Иванов, Пищеблок, Издательство АСТ: Редакция Елены Шубиной, Москва 2019. Dalej cytuję według tego wydania, w nawiasie podaję numer strony.

2 Zob. О чем новый роман Алексея Иванова „ПИЩЕБЛОК”?, https://zen. yandex.ru/media/books_reviews/o-chem-novyi-roman-alekseia-ivanova-pisceblok--5bd9720c48ed6400ab6085d6 (10.08.2020).

${ }^{3}$ А. Хлебникова, „Я предпочитаю жить по нормальным законам, а не по российским" - писатель Алексей Иванов, https://ekb.dk.ru/news/ya-predpochitayu-zhit-po-normalnym-zakonam-a-ne-po-rossiyskim-pisatel-alekseyivanov-237131698 (30.07.2020).
} 
rackiego, w którym najlepiej wybrzmią główne założenia tekstu4 Niejednokrotnie ucieka się on też do kompilacji różnych stylistyk i konwencji, co ma miejsce w powieści z 2018 roku:

Текст прошит реминисценциями - от Семьи вурдалаков, Повелителя мух, Мастера и Маргариты до готического романа. Порой чтение превращается в литературный квест, в котором не всегда просто уловить интонацию автора. И комедия, и мелодрама, и детектив 5 .

Do rozgłosu pisarza w Rosji przyczyniają się w równej mierze powieści, między innymi Геограб глобус пропил (1995), Сердие пармы (2000), Псоглавиьь (2011), Ненастье (2015) oraz kinowe ekranizacje jego utworów, a także ich adaptacje teatralne ${ }^{6}$. Iwanow zajmuje się również pisaniem scenariuszy. Najbardziej znanym filmem, przy produkcji którego współpracował on jako scenarzysta, jest wyreżyserowany przez Pawła Łungina Car (Цaps, 2008), reprezentujący Rosję na Festiwalu Filmowym w Cannes w 2009 roku.

W powieści Пищеблок Iwanow sięga, nieoczekiwanie dla wielu recenzentów i krytyków, po tematykę młodzieżową, umieszczając bohaterów i wydarzenia rozgrywające się w utworze na terenie obozu pionierskiego „Burewiestnik” latem 1980 roku w czasie trwania Igrzysk XXII Olimpiady, organizowanych przez Związek Radziecki. Korzystanie ze spektrum tematów głęboko osadzonych w realiach ZSRR w ciągu ostatniej dekady spotykane jest dość często $\mathrm{w}$ utworach przedstawicieli rosyjskiej literatury współczesnej. Iwanow dołącza do kręgu autorów, odwołujących się do radzieckiej przeszłości, co potwierdza recenzentka książki Пищеблок. Zwraca ona również uwagę na odmienność motywacji autorów, opisujących radziecką rzeczywistość, umieszczając Iwanowa na pozycji

\footnotetext{
${ }^{4}$ Zob. tamże.

${ }^{5}$ М. Башмакова, „Постоять в стороне от зла невозможно”. Писатель Алексей Иванов объяснил Марии Башмаковой, почему в романе „Пищеблок” от вампира до пионера - один шаг, https://www.kommersant. $\mathrm{ru} / \mathrm{doc} / 3791870$ (12.08.2020).

${ }^{6}$ Informacje na temat dorobku literackiego, a także adaptacji filmowych i teatralnych powieści Iwanowa znajdują się m.in. na oficjalnej stronie internetowej pisarza: http://ivanproduction.com/ (10.07.2020).
} 
pisarza komercyjnego w odróżnieniu od innych literatów, szukających w przeszłości uniwersaliów:

Романов, так или иначе обращающихся к опыту последнего советского поколения, за прошедшие годы написано немало, и Пищеблок органично встраивается в зазор между недавним Бюро проверки Александра Архангельского (действие которого тоже разворачивается во время Олимпиады) и прошлогодним Городом Брежневым Шамиля Идиатуллина (с ним книгу Иванова роднит тема пионерского лагеря). Однако если Идиатуллин (с большим успехом) и Архангельский (с меньшим) все же худо-бедно пытаются использовать советский антураж для разговора о чем-то вневременном и общечеловеческом, то Алексей Иванов эксплуатирует его с беспощадной коммерческой прямотой ${ }^{7}$.

Można przypuszczać, że powyższy sąd spowodowany jest wprowadzeniem przez Iwanowa do powieści motywu wampiryzmu, cieszącego się nieustającym powodzeniem u autorów z kręgu literatury masowej ${ }^{8}$. Wampir nie traci na popularności od wieków ${ }^{9}$, lecz nigdy istota stojąca pomiędzy światem żywych i zmarłych nie gwarantowała sukcesu wydawniczego z taką pewnością, jak na przełomie XX i XXI wieku. W związku ze stałą ich obecnością w przestrzeni kultury masowej motywy wampiryczne ulegają trywializowaniu. Ich oryginalność oraz wieloznaczność w ostatnich dekadach przyćmiewa schematyczność wątków i bohaterów wampirycznych w powieściach popularnych, przeznaczonych dla masowego odbiorcy, zainteresowanego przede wszystkim rozrywkową

\footnotetext{
${ }^{7}$ Г. Юзефович, Музей позднесоветской эпохи, теперь с вампирами Галина Юзебович - о романе „Пищеблок” Алексея Иванова, https://meduza. io/feature/2018/11/17/muzey-pozdnesovetskoy-epohi-teper-s-vampirami (10.07.2020).

${ }^{8}$ Zob. P. Gamus, Popularność literackiego tematu wampirów na przykładzie sagi „Zmierzch” Stephenie Meyer, „Acta Universitatis Lodziensis. Folia Librorum” 2014, nr 2 (19).

${ }^{9}$ Istoty przywodzące na myśl wampiry spotyka się już w tradycji starożytnej. Zob. m.in. M. Janion, Wampir. Biografia symboliczna, Wydawnictwo słowo/ obraz terytoria, Gdańsk 2002; A. Gemra, Od gotycyzmu do horroru. Wilkołak, wampir $i$ Monstrum Frankensteina $w$ wybranych utworach, Wydawnictwo Uniwersytetu Wrocławskiego, Wrocław 2008; J.P. Roux, Krew. Mity, symbole, rzeczywistość, przeł. M. Chrobak, Znak, Kraków 2013, s. 280-284.
} 
funkcją literatury. W tym kontekście sporą część współczesnych powieści wampirycznych ${ }^{10}$ możemy zaliczyć do wytworów sztuki masowej, która „[...] nie wyraża niczego niepowtarzalnego, lecz wszystko zamazuje, ujednolica, a robi to z jednego konkretnego powodu - żeby być strawą dla możliwie największej liczby ludzi"11. Powieści popularne, $w$ tym także utwory o tematyce wampirycznej, odpowiadając na oczekiwania czytelników, prezentują, jak zauważa Umberto Eco, „[...] kombinatorykę toposów już uznanych, przyjętych, lubianych przez publiczność"12 oraz „[...] uproszczoną psychologię znajdującą zastosowanie we wszystkich wersjach jednego i tego samego powieściowego archetypu"13.

Wciąż jednak zdarzają się powieści prezentujące postać wampira w niebanalny sposób, wykorzystujące jego specyfikę dla zobrazowania granicznych stanów psychiki człowieka lub wielkich tematów kultury, takich jak inność, wyobcowanie jednostki, konflikt dobra i zła oraz ich relatywność, „odczłowieczenie” istoty ludzkiej, zatracanie się człowieka w sytuacji świata ponowoczesnego itd. ${ }^{14} \mathrm{U}$ Iwanowa

${ }^{10}$ Do tego typu powieści można zaliczyć współczesne sagi wampiryczne, w których oryginalność postaci wampira i motywów z nim związanych ustępuje miejsca pieczołowitemu, kronikarskiemu wręcz zapisowi codzienności bohaterów, fantastykę niesamowitości wypiera natomiast sensacja, miłosna lub plotkarska intryga. Zob. cykl powieściowy „Sookie Stackhouse” autorstwa Charlaine Harris, rozpoczynający się powieścią Harris: Martwy aż do zmroku, przeł. E. Wojtczak, Wydawnictwo MAG, Warszawa 2009; seria powieści Pamiętniki wampirów, rozpoczynająca się powieścią Lisy J. Smith: Pamiętniki wampirów. Przebudzenie, przeł. E. Jaczewska, Wydawnictwo Amber, Warszawa 2008; wśród rosyjskich pozycji można wymienić np. trylogię Julii Nabokowej, którą otwiera jej powieść: VIP значum вампир, Издательство „Альфакнига”, Москва 2010; oraz humorystyczne powieści Andrieja Bielanina, m.in. А. Белянин, Вкус вампира, Издательство „Альфа-книга”, Москва 2005.

${ }^{11}$ N. Carroll, Filozofia sztuki masowej, przeł. M. Przylipiak, Wydawnictwo słowo/obraz terytoria, Gdańsk 2011, s. 27.

${ }^{12}$ U. Eco, Superman $w$ literaturze masowej. Powieść popularna: między retoryka a ideologia, przeł. J. Ugniewska, Państwowy Instytut Wydawniczy, Warszawa 1996, s. 96.

${ }^{13}$ Tamże, s. 97.

${ }^{14}$ Do takich powieści można zaliczyć między innymi następujące: О. Дивов, Ночной смотрящий, Эксмо, Москва 2008; В. Пелевин, Empire V, Эксмо, 
(choć przyznaje się on do celowego sięgnięcia po ten wątek, by przyciągnąć uwagę szerszego grona czytelników ${ }^{15}$ ) wampiryzm odgrywa rolę symbolicznego uogólnienia, a wampir zdecydowanie odbiega w swojej charakterystyce od współczesnych popkulturowych wampirycznych uwodzicieli. Ponadto warto docenić umiejętność dostrzegania analogii charakteru zdarzeń historyczno-politycznych, którą, według Dmitrija Bykowa, autor udowadnia w powieści Пищеблок, sugerując tożsamość sytuacji rozluźnienia reżimowego w roku olimpijskim z pozorną swobodą obywatelską ostatnich dekad:

И сейчас вокруг нас, среди духовных скреп нынешней насквозь фальшивой системы вызревает то же самое - вот почему Александр Архангельский и Алексей Иванов одновременно выпустили два романа об олимпийском 1980 годе. Тогда, хорошо помню, тоже очень чувствовалось, что „оковы тяжкие падут, темницы рухнут - и свобода вас примет радостно у входа"; но никто не догадывался, что у этой свободы будут во-оо-о-от такие клыки ${ }^{16}$.

Ruch pionierski, którego wspomnienie stanowi oś powieści $\Pi u$ щеблок, jest jednym ze zjawisk na stałe wpisanych w doświadczenie radzieckich pokoleń, kształtujących osobowości i postawy młodych Rosjan w czasach ZSRR. Iwanow „spisuje” tekst z życia, ponieważ „[...] каждый бывший Советский гражданин [...] прошел свое личностное и гражданское становление через советские детские организации, называемые 'октябрятами' и 'пионерами"'17. Pionierskie drużyny tworzone są w Związku

Москва 2006; tegoż, Батман Аполло, Эксмо, Москва 2013; E. Kostova, Historyk, przeł. M. Wroczyński, Świat Książki, Warszawa 2006; P. Watts, Ślepowidzenie, przeł. W.M. Próchniewicz, Wydawnictwo MAG, Warszawa 2013; A. Rice, Wywiad z wampirem, przeł. T. Olszewski, Dom Wydawniczy Rebis, Poznań 2005 (oraz kolejne części cyklu) i inne.

${ }^{15}$ Iwanow stwierdza: „Представьте повесть о советском пионерлагере без вампиров. Ее никто не будет читать”. Zob. А. Хлебникова, „Я предпочитаю жить по нормальным законам, а не по российским"...

${ }^{16}$ Д. Быков, Книга, автор и герой ноября: книжная полка Дмитрия Быкова, https://sobesednik.ru/dmitriy-bykov/20181116-kniga-avtor-i-geroj-noyabryaknizhnaya-polka-dmitriya-bykova (30.07.2020).

${ }^{17}$ В. Овчинников, Страна Пионерия СССР, https://proza.ru/2017/09/26/1454 (12.08.2020). 
Radzieckim powszechnie, powstają one nie tylko w szkołach, lecz także $w$ domach dziecka czy internatach ${ }^{18}$. Organizacja pionierska, oparta w swoich założeniach na zasadach ruchu skautowskiego, przeżywa stopniową metamorfozę. W latach 20. instytucja ta stawia sobie za cel czuwanie nad kształtowaniem i promowaniem właściwych form wypoczynku i czasu wolnego młodzieży, wypracowaniem dyscypliny i szacunku dla nauki i pracy ${ }^{19}$. Z czasem działalność ruchu pionierskiego ulega coraz dalej idącemu upolitycznieniu. Wychowanie patriotyczne oraz wdrażanie najmłodszych obywateli ZSRR do świadomego wykonywania zadań społecznych (uczestnictwo w pracach rolnych, budowach, zbiórkach makulatury itd.) staje się celem nadrzędnym organizacji ${ }^{20}$. Tym samym ideologia pionierstwa wspomaga $\mathrm{w}$ znacznym stopniu proces kształtowania „człowieka sowieckiego" (homo sovieticus) ${ }^{21}$, praca z młodzieżą

${ }^{18}$ Zob. В. Самойленко, Девиз пионеров. Торжественное обещание пионера. Всесоюзная пионерская организация имени В.И. Ленина, https:// fb.ru/article/327606/deviz-pionerov-torjestvennoe-obeschanie-pionera-vsesoyuznaya-pionerskaya-organizatsiya-imeni-v-i-lenina (11.08.2020).

${ }^{19}$ Zob. A. Urban-Podolan, Organizacja pionierska, pionierzy, w: D. Waloszek (red.), Encyklopedia dzieciństwa, http://encyklopediadziecinstwa.pl/index.php/ Organizacja_pionierska,_pionierzy (13.11.2020).

${ }^{20}$ Zob. tamże.

${ }^{21}$ Zob. R. Grzybowski, Cele ideowe i struktura organizacyjna Wszechzwiązkowej Organizacji Pionierskiej imienia W.I. Lenina oraz jej miejsce w systemie wychowanie nowego człowieka (homo sovieticus), „Biuletyn Historii Wychowania” 2017, nr 37, s. 63-78. Warto przy okazji przypomnieć, że określenie homo sovieticus wprowadził do dyskursu kulturowego Aleksander Zinowiew (zob. A. Zinowiew, Homo sovieticus, przeł. S. Deja, Polonia, Londyn 1984). Na polskim gruncie termin ten upowszechnił m.in. ks. Józef Tischner (zob. J. Tischner, Etyka solidarności oraz Homo sovieticus, Znak, Kraków 1992). Fenomen „człowieka radzieckiego” wyjaśnia Jan Tokarski: „Był to więc uzależniony od władzy konformista, całkowicie niezdolny do samodzielnego myślenia. Ktoś, kto preferuje, aby o wszystkim rozstrzygnął za niego Autorytet - a więc, w kontekście radzieckim, partia komunistyczna. Równie dobrze mógłby to jednak być wódz, Kościół lub państwo. Kiedy takiego Autorytetu (jednego jedynego, pisanego przez duże 'A') zabraknie, 'człowiek radziecki' nie wie zupełnie, co i jak ma robić. Wypatruje więc z niecierpliwością kogoś, kto wybawi go od 'nieszczęsnego daru wolności”' (J. Tokarski, [Listy w butelce] Homo sovieticus powraca, „Kultura Liberalna”, nr 397, 18 sierpnia 2016, https://kulturaliberalna.pl/2016/08/18/polska-homo-sovieticus-powraca/ (12.11.2020)). 
przybiera zaś postać totalnej indoktrynacji, bazującej na zniewalających młode umysły metodach treningu i tresury ${ }^{22}$. W Księdze przewodnika pionierskiego z 1952 roku czytamy:

[...] dzieci wychowują się $\mathrm{w}$ duchu komunizmu. Wyrastają [...] na gorących patriotów radzieckiej ojczyzny, bezgranicznie oddanych sprawie Lenina - Stalina, na wykształconych, kulturalnych, aktywnych i świadomych budowniczych, obywateli społeczeństwa komunistycznego ${ }^{23}$.

Ten propagandowy przekaz należy uzupełnić o informację, że podporządkowanie wychowania i edukacji młodzieży w ZSRR ideologii komunistycznej doprowadza, jak konstatuje Romuald Grzybowski, „[...] do zaniku tradycyjnych autorytetów. [...] do różnorodnych wynaturzeń typu idea wolnej miłości i pełnej swobody seksualnej"24, a także dezawuowania wartości takich jak rodzina, wiara, moralność, tradycja.

Mimo współczesnej krytyki propagandowej strony organizacji pionierskiej uczestnicy tego ruchu po latach wspominają przeszłość nie tylko pozytywnie, lecz czasami wręcz entuzjastycznie: „Самые добрые и светлые воспоминания у меня именно о пионерском периоде. Пионером быть было очень престижно"25. Iwanow również nie odżegnuje się od swojej pionierskiej aktywności. Pisarz nie rozpatruje jej jednak w kategorii agitacji politycznej. W jego retrospekcjach z dzieciństwa przewijają się raczej obrazy zabaw, spotkań z rówieśnikami, szkolnej codzienności i wakacyjnego wypoczynku:

У меня было самое обычное пионерское детство. В точности, как в романе. 80-е годы для меня - время теплое и уютное. Я читал фантастику, ходил в турпоходы, ездил по стране, гостил у бабушки в деревне. В школе дружил и ссорился, сидел на уроках, готовил политинформации, собирал

${ }^{22}$ Zob. tamże, s. 68, a także: M. Heller, Maszyna i śrubki. Jak hartował się człowiek sowiecki, Instytut Literacki, Paryż 1988, s. 154.

${ }^{23}$ Księga przewodnika pionierskiego, Państwowe Wydawnictwo „Iskry”, Warszawa 1952, s. 7.

${ }^{24}$ Zob. R. Grzybowski, Cele ideowe i struktura organizacyjna..., s. 68.

${ }^{25}$ Wspomnienie Olgi Alimowej, działaczki Komunistycznej Partii Federacji Rosyjskiej w okręgu saratowskim. Zob. Л. Шлепкина, Пионерская идеология стала мибом, https://fn-volga.ru/news/view/id/112368 (16.09.2020). 
макулатуру. Я не чувствовал духоты, гнета или чего-то подобного. Да, я видел много фальшака, но к нему тогда все были привычны: терпели его как неизбежное зло, типа так положено. В целом мне казалось, что все правильно. Я же был ребенком и не мог увидеть суть проблемы. Я не улавливал разницы между запретами родителей и запретами государства. Родители не разрешали выходить со двора, а государство не разрешало выезжать из страны. Может, если бы я был старше, мои воспоминания об СССР были мрачнее, но я тот, кто есть, и СССР для меня - солнечная страна детства ${ }^{26}$.

Sytuacja funkcjonowania „obok” ideologii nie jest zjawiskiem jednostkowym, właściwym wyłącznie dla Iwanowa. Jak pisze Viktor Tarnavskyi, „[...] przeciętny mieszkaniec ZSRR w swoim życiu często miał doświadczenia pozwalające dojść do wniosku, że oficjalna propaganda nie zawsze przystaje do rzeczywistości”27. Jako przykład zdystansowanego stosunku Rosjan do doktryn i dyrektyw autor podaje ironiczne traktowanie partyjnych zebrań, prelekcji czy szkoleń, a także wykorzystywanie imprez masowych, takich jak obchody pierwszomajowe, w charakterze spotkań towarzyskich ${ }^{28}$. W wykreowanych w powieści Пищеблок dziecięcych bohaterach utworu, wywodzących się z domów przeciętnych Rosjan, na plan pierwszy wysuwa się postawa pełna rezerwy wobec podstawowych obowiązków pioniera, wykonują je oni bez przekonania i ideowego zaangażowania. Pisarz ilustruje to dobitnie w jednej ze scen, obrazującej typowe czynności pionierskiego rozkładu dnia i ulgę dzieci po zakończeniu obowiązkowych rytuałów, wywołujących raczej zmęczenie i niechęć niż entuzjazm:

Пионеры с облегчением освободились друг от друга и предостерегающе зашипели, прижав к губам указательные пальцы.

Это действо казалось Игорю жгучим фальшаком. „Орлятский круг” подразумевал, что пионерская жизнь бескомпромиссная и опасная борьба, которая сплачивает борцов как братьев. Игоря ошпаривала неловкость, и тянуло яростно чесаться (s. 53).

\footnotetext{
${ }^{26}$ М. Башмакова, „Постоять в стороне от зла невозможно”...

${ }^{27}$ V. Tarnavskyi, Dzieci swoich czasów. Ruchy młodzieżowe w Rosji a zmiany kulturowe po upadku ZSRR, Wydawnictwo TRIO, Warszawa 2007, s. 16.

${ }^{28}$ Zob. tamże, s. 16-17.
} 
W sposób naturalny przeważa w bohaterach chęć zabawy, beztroski, swawoli, kontaktów z rówieśnikami, przeżywania przygód. Pisarz nie obdarza powieściowych pionierów rozwiniętą świadomością ideologiczną i dążeniem do skrupulatnego trzymania się pryncypiów. Chłopcy najchętniej spędzają czas na świeżym powietrzu, grając $\mathrm{w}$ piłkę lub kąpiąc się w rzece, oraz śledzą olimpijską rywalizację, dziewczęta śpiewają, rysują, ukrywają swoje sekretne skarby - zasuszone kwiatki, papierki po cukierkach, starają się oczarować kolegów. Do ulubionych wieczornych rozrywek należy opowiadanie mrożących krew w żyłach historii („„[...] Черная комната, Беглые Зэки, разные там Гробы-на-Колесиках, АвтобусыМясорубки и Синие Ногти”, s. 45), со wydaje się domeną spotkań młodzieżowych bez względu na epokę i miejsce na świecie. Bogactwo pionierskiego folkloru, który Iwanow prezentuje czytelnikom, podkreślają także recenzenci książki. W powieści znajdziemy nie tylko zbiór legend miejskich i strasznych opowieści, przekazywanych sobie przez odpoczywających nad Wołgą pionierów, lecz także wiernie odtworzoną gwarę młodzieżową, obozowe rytuały, zabawy, piosenki, tańce: „[...] собрав пионерский фольклор, детские словечки и подначки, ритуальные лагерные танцы вроде 'орлятского круга' и вечерней 'свечки', [Иванов - К.А.Т.] написал ностальгическую историю об ушедшем прошлом”29.

Spośród pionierek obozu „Burewiestnik” wyróżnia się Anastasijka, zachowująca się z należytą powagą, zawsze ubrana według wymogów regulaminu. W czasie przygotowań do uroczystego występu tylko ona przywiązuje wagę do wyboru odpowiedniego repertuaru pionierskich piosenek na zbliżający się uroczysty wieczór. Jednak pod naciskiem koleżanek dziewczyna daje za wygraną i rezygnuje z proponowanego utworu Орлята na rzecz zabawnej piosenki Чунга-Чанга („Он помнил, что Анастасийка хотела солировать на Орлятах, а Жанка хотела, чтобы пели Чунгу-Чангу, под которую можно танцевать”, s. 192). Ceną takiego kompromisu jest możliwość zaśpiewania przed publicznością, co dla Anastasijki ma

\footnotetext{
${ }^{29}$ Н. Ломкина, Главные книги осени на ярмарке поn/fiction, https://www. forbes.ru/forbeslife-photogallery/369739-glavnye-knigi-oseni-na-yarmarkenonfiction? photo=36 (12.08.2020).
} 
niemałe znaczenie. Ta wzorowa w szkole uczennica stara się wśród rówieśników w obozie potwierdzić swój status jednostki wybitnej. $\mathrm{W}$ rzeczywistości więc jedyną z pozoru świadomą misji pionierskiej osobą kierują powody ambicjonalne, co kłóci się z pionierskim kodeksem ${ }^{30}$. Wyklucza on bowiem dążenie do zaspokajania indywidualnych aspiracji, przedkładając pracę na rzecz rozwoju ojczyzny, partii komunistycznej i organizacji pionierskiej.

Depozytariuszami prymarnych ideałów pionierstwa powinni być wychowawcy młodzieży w obozie „Burewiestnik”. Do wzorowo i z przekonaniem wypełniających swoje obowiązki nie należą jednak wszyscy drużynowi. Autor odbrązawia stereotypowy wizerunek mentora bez skazy, pokazuje dorosłych $z$ ich wadami, wątpliwościami, ułomnościami, nieprzystającymi do etalonu ideologicznego przewodnika młodzieży. Instruktor sportowy na przykład stroni od organizowania zbyt wielu imprez, tłumacząc to niemożnością zapanowania nad „debilami”, jak określa podopiecznych („Вам побегать, а мне потом дэбилов искать!”, s. 29). Doktor, dbający o zdrowie dzieci w nadwołżańskim obozie, popada $\mathrm{w}$ alkoholizm, zdarza mu się także handlować spirytusem przeznaczonym do użytku medycznego. Najjaskrawszym zaś, choć nienacechowanym przez Iwanowa negatywnie, przykładem rozminięcia się postawy wychowawcy z ideałami ruchu pionierskiego i misją społecznika jest w powieści nowy opiekun Igor. Młody mężczyzna przyjeżdża do obozu, aby odbyć praktykę studencką. Już jego wygląd świadczy o dysonansie między nim a „radzieckością”. Bohater stylizuje swój ubiór („[...] и джинсы, и самодельный значок с гитаристом, и патлы”, s. 14) i fryzurę („[...] когда волосы закрывают уши - это и есть самый модный причесон”, tamże) według zachodnich trendów. Od początku pojawienia się w środowisku wychowawców daje się odczuć jego odrębność, a pozycja outsidera przyczynia się do stopniowego duchowego zbliżenia z odpowiednikiem Igora w grupie pionierów - Walerką. Chłopiec jest synem inżyniera, konstruktora $\mathrm{w}$ jednym $\mathrm{z}$ tajnych biur projektowych branży rakietowej. Ojciec wysyła go do obozu pionierskiego, aby

\footnotetext{
${ }^{30}$ Najważniejsze redakcje kodeksu pionierskiego zob. Законы пионеров СССР, http://nksmrf.ru/page/55 (20.08.2020).
} 
nawiązał kontakt z „normalnymi” dziećmi („Как человек, думающий о Родине, папа хотел, чтобы сын был ближе народу”, s. 39), co kłóci się z potrzebami Walerki, który pragnie odrobiny samotności i spokoju. Chłopiec stroni od towarzystwa, zdumiewa swoją postawą i dojrzałością ponad wiek. Rozmyśla on o istocie przyjaźni i wspólnoty, odczuwa silną potrzebę przynależności do kolektywu, choć rozumie, że jego radzieckie wydanie nie opiera się na prawdziwym zaufaniu i tolerancji. Wśród rówieśników chłopiec nie czuje się dobrze, ma świadomość swojej inności, koledzy także ją zauważają, odczuwają do niego niechęć, starają się go sobie podporządkować, co im się ostatecznie nie udaje dzięki umiejętnej ocenie sytuacji i determinacji Walerki, by nie stać się kozłem ofiarnym. Ze względu na charakteryzującą ich odmienność, głęboko w nich zakorzeniony indywidualizm i niestereotypowe postrzeganie rzeczywistości właśnie ci dwaj bohaterowie, wychowawca Igor i pionier Walerka, zostają przez Iwanowa wybrani do wypełnienia głównej roli w utworze, czyli odkrycia prawdziwego wymiaru otaczającej ich przestrzeni i tajemnych mechanizmów nią rządzących.

Pomimo że $\mathrm{w}$ świecie przedstawionym powieści $\mathrm{w}$ dziecięcych umysłach i codzienności radzieckie hasła pozostają abstrakcją, sprawą dorosłych, odległą od świata wartości nastolatków, błędem byłoby sądzić, iż agitacyjna działalność władzy ich nie dosięga. Iwanow ostrzega: „Однако для всех нас есть три Советских Союза: страна детства, социальное государство и машина идеологического подавления естественной природы человека и общества. И не надо их путать"з1. Indoktrynacyjną, tłamszącą indywidualizm i obywatelską swobodę działalność państwa radzieckiego w powieści Пищеблок ilustruje wprowadzony do utworu wspomniany już motyw wampira, który wśród wielu symbolicznych znaczeń utożsamia między innymi tyrana, ciemiężyciela ${ }^{32}$. Społeczna wykładnia mitu wampirycznego głosi, że:

Wampir, od którego zaczyna się łańcuchowy proces „wampiryzacji”, jest z reguły posiadaczem ziemskim, dziedzicem, hrabią albo księciem... [...] Władca-

\footnotetext{
${ }^{31}$ М. Башмакова, „Постоять в стороне от зла невозможно”...

${ }^{32}$ Zob. M. Janion, Wampir. Biografia symboliczna..., s. 49.
} 
-wampir potrzebuje do swego istnienia ludu: do życia niezbędna mu jest ludzka krew - zwykle krew poddanych — oraz pomoc ze strony ślepo posłusznych poddanych. Są oni tak samo niebezpieczni jak i same wampiry. Spełniają rolę aparatu urzędniczego i policji... ${ }^{33}$

Biorąc pod uwagę specyfikę funkcjonowania władzy w Związku Radzieckim od momentu bolszewickiego przełomu, panujący w tym kraju system polityczny można obrazowo określić mianem tyrana, który zastępuje „wampira arystokratycznego” i równie aktywnie, jak przedstawiciele wysoko urodzonych wyzyskiwaczy „wypija' wszelkie przejawy życia z rządzonego przez siebie państwa. [...] tyran czyni wszystko, aby poddany jego władzy człowiek nie był w stanie żyć pełnią życia" ${ }^{34}$. W przypadku ZSRR można zatem mówić, w sferze metaforycznej rzecz jasna, o wampirycznej ideologii, którą wampir upostaciowany, jednostkowy reprezentuje, co ma miejsce w analizowanym utworze.

Znamienny jest rodowód powieściowego wampira. Mamy do czynienia z szanowanym w okolicy starcem, podającym się za bohaterskiego weterana wojny domowej. Sierp Iwanycz Jeronow mieszka na terenie obozu „Burewiestnik”, spotyka się z młodzieżą, będąc dla niej źródłem wiedzy historycznej oraz wzorem do naśladowania. W rzeczywistości jest on wiejskim awanturnikiem i łupieżcą, który wykorzystuje rewolucyjny ferment, by grabić domy bogatych mieszkańców wsi. W czasie jednego z napadów dokonanych przez Sierpa Iwanycza, w tamtym czasie noszącego zwykłe imię Siergiej, i jego brata Matwieja dochodzi do makabrycznego incydentu. Bandyci, nawiązując do haseł dalekiej im w gruncie rzeczy walki klasowej, krzyczą do broniącego się oficera: „Пропил кровушки народной? [...] Теперь мы твоей крови хотим!” (s. 322). Ten zaś jako istota wampiryczna niższego rzędu zobowiązany był odpowiedzieć na żądanie krwi: „И стратилат вдруг схватил Cерегу с Матвеем за волосы и прижал рожами к ранам в своей

\footnotetext{
${ }^{33}$ Teoria Petera O. Chotjewitza. Cyt. za: M. Wydmuch, Gra ze strachem. Fantastyka grozy, Czytelnik, Warszawa 1975, s. 65-66.

${ }^{34}$ M. Rzeczycki, Wampir polityczny - uwagi o tyranii, „Civitas. Studia z filozofii polityki” 2018, nr 23, s. 84.
} 
груди - прижал, чтобы парни глотнули его бьющей толчками крови" (s. 323). W ten sposób bracia podlegają wampirycznej metamorfozie. Nowy stan pomaga im zaistnieć w rewolucyjnych, potem partyjnych strukturach. Wraz ze zmianą ludzkiej natury poprzez „chrzest” krwią mężczyźni przyjmują także nowe, jakże wymowne imiona - Sierp i Młot. Emblematy te, według opowieści wtajemniczonej w historię Jeronowów kucharki, stanowią nie tylko radzieckie, ale i wampiryczne symbole. Są to znaki ochronne krwiopijców, obrazujące odpowiednio: sierp - księżyc w fazie, gdy wampiry odczuwają głód krwi, oraz młot - narzędzie śmierci wampira, wbijające osinowy kołek w jego serce. Do tego można dodać i inne analogie pomiędzy symboliką radziecką i pionierską a wampiryczną i demoniczną. Czerwień flagi przywodzi na myśl kolor krwi, pięcioramienna gwiazda wywołuje natomiast analogie z pentagramem. Taka wykładnia radzieckich symboli zadaje kłam szumnie brzmiącym hasłom, którymi przywódcy ZSRR mamią kolejne pokolenia Rosjan.

Sierp Iwanycz, reprezentant ideologicznych przewodników narodu, nosi wampiryczne znamię oszusta, hipnotyzera, który potrafi zmanipulować ofiarę. Iwanow w opisie wampirycznego bohatera eksponuje oczy, przenikające obserwowanego człowieka, obezwładniające ofiarę, uniemożliwiające przeciwstawienie się jego woli. Przeistoczenie w wampira następuje w sposób tradycyjny. Sierp Iwanycz naznacza kolejnych wybrańców zdradliwym wampirycznym pocałunkiem ${ }^{35}$. Czerwony ślad po pocałunku-ugryzieniu symbolicznie imituje w powieści czerwona pionierska chustka, zapominana przez dzieci na początku turnusu i pieczołowicie noszona przez młodych adeptów wampiryzmu. Pijąc krew kolejnych mieszkańców obozu, starzec podporządkowuje sobie stopniowo coraz szersze grono bezwzględnie posłusznych sług ${ }^{36}$ („Укушен-

\footnotetext{
${ }^{35} \mathrm{O}$ wymowie wampirycznego pocałunku pisze Adrianne Blue. Zob. tejże, Pocałunek. Od metafizyki do erotyki, przeł. K. Rabińska, Państwowy Instytut Wydawniczy, Warszawa 1998, s. 135-146.

${ }^{36}$ Motyw ten przypomina sposób działania najbardziej znanego w kulturze wampira - powieściowy hrabia Dracula podporządkowuje sobie w podobny sposób Renfielda, który staje się wiernym sługą wampira, wielbiącym go i spełniającym bez protestu każde jego zlecenie.
} 
ный не просто служит вампиру. Он ему подчинен. Порабощен”, s. 248), którzy po ugryzienie nie zyskują statusu równego wampirowi przywódcy, są to istoty pośledniejszego rzędu, w powieści określane mianem „пиявцы”. Umysły podporządkowanych głównemu krwiopijcy sług zatracają zdolność racjonalnej oceny sytuacji, odbierają rzeczywistość w takiej postaci, w jakiej wampir chce im ją pokazać, egzystują w nieuzasadnionym poczuciu euforii: „Да ты не чувствовал никогда, как я сейчас чувствую! Ты не жил, как я живу” (s. 354). Jednocześnie instynktownie czują oni konieczność idealnego dopasowania się do środowiska, w którym nadal funkcjonują, co usypia czujność otoczenia:

Так вот почему пиявцы становятся правильными пионерами, которые не только ведут себя хорошо, но и выглядят как надо! С помощью своей правильности они прячутся и от людей, и от солнца! (s. 326).

Przełamać oddziaływanie wampira, uchronić się przed zniewoleniem mogą tylko jednostki o silnym poczuciu niezależności, przedkładające prawdę samotności ponad zakłamane relacje ze światem. W takiej właśnie pozycji stawia Iwanow wspomnianych wcześniej Igora i Walerkę. Chłopiec pierwszy zauważa anomalie w zachowaniu zainfekowanych wampiryzmem kolegów. Jego wewnętrzna siła pozwala mu przetrwać („Древнее зло не может одолеть человека, если человек не уступает ему свою волю”, s. 411), połączyć siły z opiekunem i doprowadzić do zguby Sierpa Iwanycza. Więź Walerki i Igora to przykład, że w radzieckiej rzeczywistości możliwa jest nowa jakość międzyludzkich zależności. Chłopiec znajduje w niej wreszcie spełnienie marzenia o idealnym kolektywie, który łączy ludzi, nie niszcząc indywidualności, osobistych potrzeb i dążenia do ich realizacji. W tym sprzymierzeniu pioniera i wychowawcy Iwanow przywołuje istotę socjalizmu, będącego przecież w teorii ideą łączącą suwerenne byty, korzystające ze wspólnie wypracowanych, sprawiedliwie podzielonych dóbr, działające na korzyść wszystkich w imię dobra ogółu. W procesie realizacji tej idei jej główne zamierzenia ulegają jednak wypaczeniu, staje się ona przyczynkiem do powstawania stosunków zależności i poddaństwa. Przedstawiony w analizowanej powieści stan zaślepienia mieszkańców pionierskiej 
siedziby, bezwolne podążanie za wampirycznym przywódcą i bezwarunkowa wiara w prawdziwość snutej przez niego wizji odzwierciedlają realia Kraju Rad. Obóz „Burewiestnik” w koncepcji Iwanowa symbolizuje państwo, będące jednocześnie całym światem dla opisanych w powieści pionierów. W momencie odkrycia przez Igora i Walerkę tajemnicy Sierpa Iwanycza świat ten nagle traci podstawy: „[...] такой привычный, понятный и родной, оказался ненастоящим. Не пионерлагерь, а пищеблок. Не мораль, а маскировка. Не символы государства, а магические обереги. Не история, а ложь” (s. 327). Pisarz prezentuje organizację pionierską przez pryzmat wampirycznego zniewolenia. To interesujące i oryginalne w literaturze rosyjskiej ujęcie tematu. Iwanow odwołuje się do „[...] rozumienia wampiryzmu jako zarazy, nie tylko w wymiarze rzeczywistym, fizycznym, ale także symbolicznym, metaforycznym" ${ }^{37}$. Totalitarny ustrój Związku Radzieckiego jest utożsamiany z epicentrum choroby, stopniowo ogarniającej cały kraj i jego mieszkańców. Radzieccy obywatele, poddani stałej indoktrynacji, podobni są do osób w hipnotycznym transie, wypełniających bez oporu wolę hipnotyzera. Przedstawieni w analizowanej powieści pionierzy i ich opiekunowie to reprezentanci społeczeństwa radzieckiego, które pozostaje przez wiele dekad pod działaniem ideologicznego „krwiopijcy”. Przywołanie przez Iwanowa postaci wampira $\mathrm{z}$ jego tradycyjnymi atrybutami pozwala odbrązowić mit pionierstwa i unaocznić rzeczywistą polityczną działalność tego ruchu, mającą na celu ukształtowanie właściwej postawy młodych obywateli: „[...] политическая направленность деятельности пионерской организации была связана со всеми сторонами ее работы по воспитанию юного гражданина"38. Przywódcy wszelkich systemów totalitarnych zwracają swoją uwagę ku młodzieży, tworzącej przyszłość narodu:

„Кому принадлежит молодежь - тому принадлежит будущее”. Эта фраза, сказанная главным идеологом нацистского режима, вполне могла бы

\footnotetext{
${ }^{37}$ A. Gemra, Od gotycyzmu do horroru..., s. 211.

${ }^{38}$ Н. Гудинова, „Кому принадлежит молодежь - тому принадлежит будущеeе", https://nsportal.ru/shkola/sotsialnaya-pedagogika/library/2013/03/13/ komu-prinadlezhit-molodezh-tomu-prinadlezhit (1.09.2020).
} 
стать и девизом для коммунистических лидеров, строивших молодежные организации Советского Союза ${ }^{39}$.

Iwanow, snując nostalgiczną opowieść o czasach własnego dzieciństwa, ale także przeszłości wielu rosyjskich pokoleń, ukazuje procesy podprogowego oddziaływania państwa i władzy na życie i postawy młodych Rosjan. Jego ocena rzeczywistości, choć niewyrażona w sposób dosadny, daleka jest od pozytywnej wizji. Jednocześnie w kreacji głównych bohaterów utworu, którzy podejmują się epokowego wyzwania i pokonują zło, pobrzmiewają echa nadziei.

\section{REFERENCES}

Bashmakova, Mariya. “'Postoyat' v storone ot zla nevozmozhno.' Pisatel' Aleksey Ivanov ob"yasnil Marii Bashmakovoy, pochemu v romane 'Pishcheblok' ot vampira do pionera — odin shag." https://www.kommersant.ru/doc/3791870. Accessed 12 Aug. 2020 [Башмакова, “Постоять в стороне от зла невозможно.' Писатель Алексей Иванов объяснил Марии Башмаковой, почему в романе 'Пищеблок' от вампира до пионера - один шаг.' https:// www.kommersant.ru/doc/3791870. Дата обращения: 12 августа 2020].

Belyanin, Andrey. Vkus vampira. Moskva: Izdatel'stvo “Al'fa-kniga”, 2005 [Белянин, Андрей. Вкус вампира. Москва: Издательство “Альфа-книга," 2005].

Blue, Adrianne. Pocałunek. Od metafizyki do erotyki. Transl. Rabińska, Krystyna. Warszawa: Państwowy Instytut Wydawniczy, 1998.

Bykov, Dmitriy. "Kniga, avtor i geroy noyabrya: knizhnaya polka Dmitriya Bykova." https://sobesednik.ru/dmitriy-bykov/20181116-kniga-avtor-i-gerojnoyabrya-knizhnaya-polka-dmitriya-bykova. Accessed 30 Jul. 2020 [Быков, Дмитрий. “Книга, автор и герой ноября: книжная полка Дмитрия Быкова.” https://sobesednik.ru/dmitriy-bykov/20181116-kniga-avtor-i-geroj-noyabrya-knizhnaya-polka-dmitriya-bykova. Дата обращения: 30 июля 2020].

Carroll, Noël. Filozofia sztuki masowej. Transl. Przylipiak, Mirosław. Gdańsk: Wydawnictwo słowo/obraz terytoria, 2011.

Divov, Oleg. Nochnoy smotryashchiy. Moskva: Eksmo, 2008 [Дивов, Олег. Ночной смотрящий. Москва: Эксмо, 2008].

Eco, Umberto. Superman w literaturze masowej. Powieść popularna: między retorykq a ideologia. Transl. Ugniewska, Joanna. Warszawa: Państwowy Instytut Wydawniczy, 1996.

Gamus, Paula. "Popularność literackiego tematu wampirów na przykładzie sagi 'Zmierzch' Stepheanie Meyer.' Acta Universitatis Lodziensis. Folia Librorum, no. 2 (19), 2014: 9-24.

\footnotetext{
${ }^{39}$ А. Новомлинская, Пионерия, https://urokiistorii.ru/article/231 (22.09.2020).
} 
Gemra, Anna. Od gotycyzmu do horroru. Wilkołak, wampir i Monstrum Frankensteina $w$ wybranych utworach. Wrocław: Wydawnictwo Uniwersytetu Wrocławskiego, 2008.

Grzybowski, Romuald. “Cele ideowe i struktura organizacyjna Wszechzwiązkowej Organizacji Pionierskiej imienia W.I. Lenina oraz jej miejsce w systemie wychowanie nowego człowieka (homo sovieticus)." Biuletyn Historii Wychowania, no. 37, 2017: 63-78.

Gudinova, Natal'ya. “Komu prinadlezhit molodezh' - tomu prinadlezhit budushcheye." https://nsportal.ru/shkola/sotsialnaya-pedagogika/library/ 2013/03/13/komu-prinadlezhit-molodezh-tomu-prinadlezhit. Accessed 1 Sep. 2020 [Гудинова, Наталья. “Кому принадлежит молодежь - тому принадлежит будущее.” https://nsportal.ru/shkola/sotsialnaya-pedagogika/ library/2013/03/13/komu-prinadlezhit-molodezh-tomu-prinadlezhit. Дата обращения: 1 сентября 2020].

Harris, Charlaine. Martwy aż do zmroku. Transl. Wojtczak, Ewa. Warszawa: Wydawnictwo MAG, 2009.

Heller, Michał. Maszyna i śrubki. Jak hartował się człowiek sowiecki. Paryż: Instytut Literacki, 1988.

Ivanov, Aleksey. Pishcheblok. Moskva: Izdatel'stvo AST: Redaktsiya Yeleny Shubinоу, 2019 [Иванов, Алексей. Пищеблок. Москва: Издательство АСТ: Редакция Елены Шубиной, 2019].

Janion, Maria. Wampir. Biografia symboliczna. Gdańsk: Wydawnictwo słowo/obraz terytoria, 2002.

Khlebnikova, Anna. “'Ya predpochitayu zhit' po normal'nym zakonam, a ne po rossiyskim' - pisatel' Aleksey Ivanov.” https://ekb.dk.ru/news/ya-predpochitayu-zhit-po-normalnym-zakonam-a-ne-po-rossiyskim-pisatel-aleksey-ivanov-237131698. Accessed 30 Jul. 2020 [Хлебникова, Анна. “'Я предпочитаю жить по нормальным законам, а не по российским' - писатель Алексей Иванов.” https://ekb.dk.ru/news/ya-predpochitayu-zhit-po-normalnym-zakonam-a-ne-po-rossiyskim-pisatel-alekseyivanov-237131698. Дата обращения: 30 июля 2020].

Kostova, Elizabeth. Historyk. Transl. Wroczyński, Michał. Warszawa: Świat Książki, 2006.

Księga przewodnika pionierskiego. Warszawa: Państwowe Wydawnictwo "Iskry," 1952.

Lomkina, Natal'ya. “Glavnyye knigi oseni na yarmarke non/fiction.” https:// www.forbes.ru/forbeslife-photogallery/369739-glavnye-knigi-oseni-nayarmarke-nonfiction?photo=36. Accessed 12 Aug. 2020 [Ломкина, Наталья. “Главные книги осени на ярмарке non/fiction.” https://www.forbes. ru/forbeslife-photogallery/369739-glavnye-knigi-oseni-na-yarmarke-nonfiction?photo=36. Дата обращения: 12 августа 2020].

Nabokova, Yuliya. VIP znachit vampir. Moskva: Izdatel'stvo “Al'fa-kniga," 2010 [Набокова, Юлия. VIP значит вампир. Москва: Издательство “Альфакнига," 2010]. 
Novomlinskaya, Anna. "Pioneriya." https://urokiistorii.ru/article/231. Accessed 22 Sep. 2020 [Новомлинская, Анна. “Пионерия." https://urokiistorii.ru/article/231. Дата обращения: 22 сентября 2020].

“O chem novyy roman Alekseya Ivanova 'PISHCHEBLOK’?” https://zen.yandex. ru/media/books_reviews/o-chem-novyi-roman-alekseia-ivanova-pisceblok-5bd9720c48ed6400ab6085d66. Accessed 10 Aug. 2020 [О чем новый роман Алексея Иванова 'ПИЩЕБЛОК'?” https://zen.yandex.ru/media/books_ reviews/o-chem-novyi-roman-alekseia-ivanova-pisceblok--5bd9720c48ed6400ab6085d6. Дата обращения: 10 августа 2020].

Ovchinnikov, Vitaliy. “Strana Pioneriya SSSR.” https://proza.ru/2017/09/26/1454. Accessed 12 Aug. 2020 [Овчинников, Виталий. “Страна Пионерия СССР.” https://proza.ru/2017/09/26/1454. Дата обращения: 12 августа 2020].

Pelevin, Viktor. Batman Apollo. Moskva: Eksmo, 2013 [Пелевин, Виктор. Батман Аполло. Москва: Эксмо, 2013].

Pelevin, Viktor. Empire V. Moskva: Eksmo, 2006 [Пелевин, Виктор. Empire V. Москва: Эксмо, 2006].

Rice, Anne. Wywiad z wampirem. Transl. Olszewski, Tomasz. Poznań: Dom Wydawniczy Rebis, 2005.

Roux, Jean-Paul. Krew. Mity, symbole, rzeczywistość. Transl. Chrobak, Marzena. Kraków: Znak, 2013.

Rzeczycki, Michał. "Wampir polityczny - uwagi o tyranii." Civitas. Studia z filozofii polityki, no. 23, 2018: 75-99.

Samoylenko, Vyacheslav. "Deviz pionerov. Torzhestvennoye obeshchaniye pionera. Vsesoyuznaya pionerskaya organizatsiya imeni V.I. Lenina." https://fb.ru/ article/327606/deviz-pionerov-torjestvennoe-obeschanie-pionera-vsesoyu znaya-pionerskaya-organizatsiya-imeni-v-i-lenina. Accessed 11 Aug. 2020 [Самойленко, Вячеслав. “Девиз пионеров. Торжественное обещание пионера. Всесоюзная пионерская организация имени В.И. Ленина.” https:// fb.ru/article/327606/deviz-pionerov-torjestvennoe-obeschanie-pionera-vs esoyuznaya-pionerskaya-organizatsiya-imeni-v-i-lenina. Дата обращения: 11 августа 2020].

Shlepkina, Lyusya. "Pionerskaya ideologiya stala mifom.” https://fn-volga.ru/ news/view/id/112368. Accessed 16 Sep. 2020 [Шлепкина, Люся. “Пионерская идеология стала мифом." https://fn-volga.ru/news/view/id/112368. Дата обращения: 16 сентября 2020].

Smith, Lisa Jane. Pamiętniki wampirów. Przebudzenie. Transl. Jaczewska, Edyta. Warszawa: Wydawnictwo Amber, 2008.

Tarnavskyi, Viktor. Dzieci swoich czasów. Ruchy młodzieżowe w Rosji a zmiany kulturowe po upadku ZSRR. Warszawa: Wydawnictwo TRIO, 2007.

Tischner, Józef. Etyka solidarności oraz Homo sovieticus. Kraków: Znak, 1992.

Tokarski, Jan. "[Listy w butelce] Homo sovieticus powraca." Kultura Liberalna, no. 397, 18 Aug. 2016, https://kulturaliberalna.pl/2016/08/18/polska-homo-sovieticus-powraca. Accessed 12 Nov. 2020.

Urban-Podolan, Aleksandra. "Organizacja pionierska, pionierzy." Encyklopedia dzieciństwa. Ed. Waloszek, Danuta. http://encyklopediadziecinstwa.pl/index. php/Organizacja_pionierska,_pionierzy. Accessed 13 Nov. 2020. 
Watts, Peter. Ślepowidzenie. Transl. Próchniewicz, Wojciech M. Warszawa: Wydawnictwo MAG, 2013.

Wydmuch, Marek. Gra ze strachem. Fantastyka grozy. Warszawa: Czytelnik, 1975.

Yuzefovich, Galina. "Muzey pozdnesovetskoy epokhi, teper' s vampirami. Galina Yuzefovich - o romane 'Pishcheblok' Alekseya Ivanova." https://meduza. io/feature/2018/11/17/muzey-pozdnesovetskoy-epohi-teper-s-vampirami. Accessed 10 Jul. 2020 [Юзефович, Галина. “Музей позднесоветской эпохи, теперь с вампирами. Галина Юзефович - о романе 'Пищеблок’ Алексея Иванова." https://meduza.io/feature/2018/11/17/muzey-pozdnesovetskoyepohi-teper-s-vampirami. Дата обращения: 10 июля 2020].

"Zakony pionerov SSSR.” http://nksmrf.ru/page/55. Accessed 20 Aug. 2020 [“3aконы пионеров СССР.” http://nksmrf.ru/page/55. Дата обращения: 20 августа 2020].

Zinowiew, Aleksander. Homo sovieticus. Transl. Deja, Stanisław. Londyn: Polonia, 1984. 